\title{
Tinjauan Pustaka $\mid$ TERAPI BERMAIN MAGgalenceng SEBAGAI METODE UNTUK MENURUNKAN KECEMASAN PADA ANAK USIA SEKOLAH YANG MENJALANI HOSPITALISASI: A LITERATURE REVIEW Musdalipa, Almasari Kanita, Kasmawati, Sri Hartina HM Mahasiswa Jurusan Keperawatan Fakultas Kedokteran dan IImu Kesehatan UIN Alauddin Makassar
}

\begin{abstract}
ABSTRAK
Pendahuluan:United Nations Children's Fund (UNICEF) (2012) menyatakan bahwa prevalensianak yang menjalaniperawatandi rumahsakitsekitar $84 \%$. Kementerian Kesehatan Republik Indonesia (KEMENKES RI) (2015) menyatakan hasil surveinya berdasarkan Angka kesakitan anak di Indonesia menurut kelompok usia 02 tahun sebesar $15,14 \%$,usia3-5tahun sebesar 25,8\%,usia 6-12 tahun sebanyak 13,91\%. Hospitalisasi adalah masuknya individu ke rumah sakit sebagai pasien dengan berbagai alasan seperti pemeriksaan diagnostik, prosedur operasi, perawatan medis, pemberian obat dan menstabilkan atau pemantauan kondisi tubuh. Hospitalisasi dapat menimbulkan krisis pada kehidupan anak karena ketika di rumah sakit, anak harus menghadapi lingkungan yang asing, pemberian asuhan yang tidak dikenal, dan gangguan terhadap gaya hidup mereka, sehingga anak dapat mengalami kecemasaan akibat perubahan, baik pada status kesehatan maupun lingkungan dalam sehari-hari. Salah satu metode yang dapat digunakan untuk menurunkan kecemasan pada anak yang menjalani hospitalisasi adalah terapi bermain maggalenceng. Maggalencengceng adalah permainan memindah-mindahkan butir-butir batu atau biji buah asem ke dalam lubang-lubang pada sebidang kayu atau plastik.

Metode:Penulisan ini, bersifat library research (penelitian pustaka) yang disajikan secara deskriptif melalui beberapa literatur yang relevan dengan tulisan ini.

Hasil dan Pembahasan:Terapi bermain adalah salah satu aspek penting dari kehidupan anak dan efektif untuk mengatasi stress ketika dirawat di rumah sakit. Bermain maggalenceng dapat merangsang keluarnya hormon kebahagiaan, yaitu endorphin dan serotonin. Endorphin tidak saja digunakan untuk merilekskan bagian otot dan saraf, atau sebagai zat imun kita, melainkan juga mampu megurangi rasa sakit. Serotonin adalah zat yang membantu menjaga suasana hati kita dibawah kontrol pikiran, menenangkan kecemasan, dan mengurangi depresi.

Kesimpulan:Terapi bermain maggalenceng efektif digunakan sebagai metode untuk menurunkan kecemasan pada anak usia sekolah. Selain mampu mengaktifkan otak anak dan menurunkan kecemasan, maggalenceng juga memiliki nilai kearifan lokal dan mengandung nilai-nilai budaya tradisional Indonesia.
\end{abstract}

Kata Kunci: Kecemasan, Terapi Bermain Maggalenceng, Hospitalisasi, Anak Usia Sekolah

\begin{abstract}
Introduction: The United Nations Children's Fund (UNICEF) (2012) states that the prevalence of children undergoing hospitalization is $84 \%$. The Ministry of Health of the Republic of Indonesia (KEMENKES RI) (2015) states the results of the survey are based on child morbidity in Indonesia by age group $0-2$ years of $15.14 \%$, age $3-5$ years by $25.8 \%, 6-12$ years age $13.91 \%$. Hospitalization is the entry of an individual to the hospital as a patient for various reasons such as diagnostic examination, surgical procedure, medical care, drug delivery and stabilizing or monitoring of body condition. Hospitalization can lead to a crisis in the lives of children because when in the hospital, the child must face a strange environment, the provision of unfamiliar care, and disruption to their lifestyle, so that the child can experience the arousal due to changes, both on health status and environment in day-to- day. One method that can be used to reduce anxiety in children who undergo hospitalization is a therapy play maggalenceng. Maggalencengceng is a game to move rock or asem seeds into holes on a piece of wood or plastic.
\end{abstract}

Method: This writing, is a library research (literature research) presented descriptively through several literature relevant to this paper.

Results and Discussion: Play therapy is one of the most important aspects of a child's life and is effective in dealing with stress when hospitalized. Play maggalenceng can stimulate the release of hormones of happiness, namely endorphin and serotonin. Endorphins are not only used to relax the muscles and nerves, or as our immune substances, but also can reduce the pain. Serotonin is a substance that helps keep our mood under mind control, calms anxiety, and reduces depression.

Conclusion: Maggalenceng play therapy is effectively used as a method to reduce anxiety in school-age children. In addition to being able to activate the child's brain and reduce anxiety, maggalenceng also has a value of local wisdom and contains traditional Indonesian cultural values.

Keywords: Anxiety, Maggalenceng Play Therapy, Hospitalization, School-Age Children 


\section{PENDAHULUAN}

United

Nations Children's

Fund(UNICEF)(2012) menyatakan bahwa prevalensianak yang menjalaniperawatandi rumahsakitsekitar 84\%.Disease Control, National Hospital Discharge Survey (NHDS) (2004) dalam Apriliawati ${ }^{1}$ menjelaskan bahwa lebih dari 1,6 juta anak diantaranya anak usia 2-6 tahun menjalani hospitalisasi disebakan karena injury dan berbagai penyebab lainnya. Kain (2006) dalam Apriliawati ${ }^{1}$ juga menyatakan hasil surveinya bahwa di Amerika Serikat, diperkirakan lebih dari 5 juta anak menjalani hospitalisasi karena prosedur pembedahan dan lebih dari $50 \%$ dari jumlah tersebut anak mengalami kecemasan dan stres.

Badan Pusat Statistik Nasional (BPS)2013 menyatakan bahwa jumlah populasi anak di Indonesia yaitu 82.840 .600 jiwa anak dari 245.569.381 jiwa penduduk. Kesehatan Nasional ${ }^{2}$, juga menerangkan jumlah anak usia prasekolah di Indonesia sebesar $72 \%$ dari jumlah total penduduk Indonesia, dan diperkirakan dari 35 per 100 anak menjalani hospitalisasi dan $45 \%$ diantaranya mengalami kecemasan.Selain membutuhkan perawatan yang spesial dibanding pasien lain, waktu yang dibutuhkan untuk merawat penderita anak-anak 20\%-45\% melebihi waktu untuk merawat orang dewasa. Anak yang dirawat di rumah sakit akan mempengaruhi kondisi fisik dan psikologinya.

Kementrian Kesehatan Republik Indonesia (KEMENKES RI) 2015 menyatakan hasil surveinya berdasarkan Angka kesakitan anak di Indonesia menurut kelompok usia 0-2 tahun sebesar $15,14 \%$, usia 3-5 tahun sebesar 25,8\%,usia6-12 tahun sebanyak $13,91 \%$ apabila dihitung dari keseluruhan jumlah penduduk, dapat disimpulkan bahwa angka kesakitan anak pra sekolah yang paling tinggi yaitu 25,8\%. Berdasarkan hasil survey kesehatan ibu dan anak pada tahun 2015didapatkan data bahwa dari 1.425 anak mengalami dampak hospitalisasi, dan 33,2\% diantaranya mengalami dampak hospitalisasi berat, $41,6 \%$ mengalami dampak hospitalisasi sedang, dan $25,2 \%$ mengalami dampak hospitalisasi ringan.

Hospitalisasi adalah masuknya individu ke rumah sakit sebagai pasien dengan berbagai alasan seperti pemeriksaan diagnostik, prosedur operasi, perawatan medis, pemberian obat dan menstabilkan atau pemantauan kondisi tubuh ${ }^{3}$. Hospitalisasi dapat menimbulkan krisis pada kehidupan anak karena ketika di rumah sakit, anak harus menghadapi lingkungan yang asing, pemberian asuhan yang tidak dikenal, dan gangguan terhadap gaya hidup mereka, sehingga anak dapat mengalami kecemasaan akibat perubahan, baik pada status kesehatan maupun lingkungan dalam sehari-hari ${ }^{4}$. Jadi, salah satu dampak yang dapat ditimbulkan akibat hospitalisasi pada anak adalah kecemasan.

Kecemasan adalah gangguan alam perasaan yang ditandai dengan perasaan ketakutan atau kekhawatiran yang mendalam dan berkelanjutan, tidak mengalami gangguan dalam kenyataan, kepribadian masih tetap utuh atau tidak mengalami keretakan kepribadian normal ${ }^{5}$. Berdasarkan aspek klinis, kecemasan dapat dijumpai pada orang yang menderita stress normal, sakit fisik berat lama dan kronik, serta pada orang dengan gangguan psikiatri berat. Kecemasan yang berkepanjangan dapat menjadi patologis dan menghasilkan berbagai gejala hiperaktivitas otonom pada sistem musculoskeletal,

kardiovaskuler, gastrointestinal bahkan genitourinarius. Respon kecemasan yang berkepanjangan dinamakan gangguan kecemasan ${ }^{6}$.

Apabila kecemasan pada anak mengakibatkan terus-menerus dapat pada penurunan respon imun, sehingga dapat berpengaruh terhadap proses penyembuhannya, lama perawatan bertambah, dan mempercepat terjadinya komplikasi penyakit yang tidak diinginkan ${ }^{8}$.

Oleh karena itu, dibutuhkan intervensi dalam mengatasi kecemasan pada anak selama hospitalisasi agar dapat memfasilitasi anak dalam mengekspresikan perasaannya. Apabila kecemasan anak selama hospitalisasi dapat teratasi, maka akan mendukung koping yang efektif dan mendukung kelancaran

perawat dalam memberikan asuhan keperawatan. Untuk itu, anak memerlukan media yang dapat mengekspresikan perasaan tersebut dan mampu bekerja sama dengan petugas kesehatan selama dalam perawatan. Salah satu media yang paling efektif adalah melalui kegiatan bermain.

Kegiatan bermain merupakan bagian yang penting dalam proses tumbuh kembang anak di semua bidang kehidupan baik fisik, intelektual, emosi dan sosial ${ }^{9}$. Permainan yang diberikan kepada anak sebaiknya pemainan yang bersifat terapeutik dan edukatif. Hal ini sejalan dengan penelitian yang dilakukan oleh Sysnawati $\mathrm{dkk}^{9}$. tentang 
menurunkan kecemasan unak usia sekolah selama hospitlisasi dengan terapi bermain, didapatkan hasil bahwa tingkat kecemasan anak usia sekolah sebelum diberikan terapi bermain all tangled up yaitu berada pada tingkat kecemasan sedang. Terapi bermain all tangled up mampu menurunkan kecemasan anak usia sekolah yang sedang mendapatkan perawatan di rumah sakit dari tingkat kecemasan sedang menjadi kecemasan ringan pada kelompok intervensi.

Namun, melihat fenomena yang terjadi di masyarakat bahwa permainan anak-anak saat ini didominasi oleh teknologi canggih seperti gadget dan membuat permainan tradisional terlupakan. Permainan yang mengandung makna kearifan lokal menjadi sebuah hal yang sulit dipertahankan. Jika digali lebih dalam, ternyata makna dibalik nilai-nilai permainan tradisional mengandung pesan-pesan moral dengan muatan kearifan lokal (local wisdom) yang luhur, sangat sayang jika generasi sekarang tidak mengenal dan menghayati nilai-nilai yang diangkat dari keanekaragaman suku-suku bangsa di Indonesia. Salah satu permainan tradisional bangsa Indonesia adalah congklak, yang dalam bahasa Bugis-Makassar adalah maggalenceng. Permainan maggalenceng adalah merupakan sebuah permainan yang dimainkan oleh dua orang, memakai sebuah papan aggalenceng (congklak) yang memiliki 16 lubang, menggunakan sejenis cangkang kerang digunakan sebagai biji maggalenceng dan jika tidak ada, kadangkala digunakan bijibiji dari tumbuh-tumbuhan dan batu-batu kecil $^{10}$.

Berdasarkan pemaran latar belakang, maka peneliti tertarik untuk mengangkat judul "Terapi Bermain Maggalenceng sebagai Metode Untuk Menurunkan Kecemasan pada Anak Usia Sekolah yang Menjalani Hospitalisasi: A Literature Review'.

\section{METODE}

\section{Jenis Tulisan}

Tulisan ini bersifat library research (penelitian pustaka) yang disajikan secara deskriptif melalui beberapa literatur yang relevan dengan tulisan ini.

\section{Teknik Pengumpulan Data}

Data karya tulis ini diperoleh dari beberapa literatur buku, jurnal yang membahas tentang dampak pada anak yang hospitalisasi serta penggunaan permainan tradisional sebagai terapi penurun kecemasan. Keuntungannya adalah data yang didapatkan jelas dan akurat.

\section{Pengolahan Data}

Setelah dilakukan pengumpulan data dan informasi, semua data dan informasi tersebut diseleksi kerelevanan dengan masalah yang dikaji. Untuk menyajikan masalah yang akan dibahas maka data yang terkumpul di analisis secara deskriptif.

\section{Analisis dan Sintesis}

a. Menggunakanmetodeanalisis

komparatif untuk melihat perbandingan antara pikiran utama karya tulis ini dengan beberapa teori yang relevan.

b. Menggunakan metode analisis deskripsi untuk mengolah dan menafsirkan data yang telah diperoleh sehingga didapatkan gambaran jelas tentang keadaan sebenarnya pada objek yang dikaji.

\section{KAJIAN PUSTAKA}

\section{Konsep Bermain Maggalenceng}

Ketika masa anak sudah memasuki masa bermain atau istilah lain disebut sebagai masa todler, maka akan selalu membutuhkan kesenangan pada dirinya disitulah anak membutuhkan suatu permainan, maka tidak terlalu heran masa anak-anak sangat identik dengan masa bermain karena perkembangan anak akan mulai diasah sesuai dengan kebutuhannya di saat tumbuh kembang. Akan tetapi banyak orang yang menganggap masa bermain pada anak tidaklah mendapat suatu perhatian secara khusus, sehingga banyak sekali orang tua yang membiarkan anak tanpa memberikan pendidikan terhadap permainan yang dimiliki anak. Untuk itu, sebelum memahami alat permainan pada anak secara khusus maka lebih dahulu harus mengenal pengertian bermain pada anak yang ditinjau dari aspek keperawatan $^{\mathbf{1 1}}$

Perkembangan anak-anak tidak lepas dari bermain. Bagi anak, seluruh aktivitasnya adalah bermain yang juga mencakup bekerja, kesenangannya dan metode bagaimana mereka mengenal dunia. Ketika bermain, anak tidak hanya sekedar melompat, melempar atau berlari, tetapi mereka bermain dengan menggunakan seluruh emosi, perasaan, 
dan pikirannya. Demikian juga pada anak sakit, Bermain dapat digunakan sebagai media psiko terapi atau pengobatan terhadap anak yang dikenal dengan sebutan terapi bermain ${ }^{4}$

\section{Definisi Bermain}

Bermain merupakan suatu aktivitas dimana anak dapat melakukan atau mempraktikkan memberikan ekspresi terhadap pemikiran, menjadi kreatif, mempersiapkan diri untuk berperan dan berperilaku dewasa. Sebagai suatu aktivitas yang memberikan stimulasi dalam kemampuan keterampilan, kognitif, dan afektif maka sepatutnya diperlukan suatu bimbingan, mengingat bermain bagi anak merupakan suatu kebutuhan bagi dirinya sebagaimana kebutuhan lainnya seperti kebutuhan makan, kebutuhan rasa aman, kebutuhan kasih sayang, dan lain-lain ${ }^{17}$.

Bermain merupakan kegiatan atau simulasi yang sangat tepat untuk anak. Bermain dapat meningkatkan daya pikir anak untuk mendayagunakan aspek emosional, sosial serta fisiknya serta dapat meningkatkan kemampuan fisik, pengalaman, dan pengetahuan serta keseimbangan mental anak ${ }^{4}$.

\section{Fungsi Bermain}

Adapun fungsi bermain, antara lain ${ }^{12}$ :

1) Perkembangan sensoris-motorik Dalam hal ini permainan akan membantu perkembangan gerak halus dan pergerakan kasar anak dengan cara memainkan suatu obyek yang sekiranya anak merasa senang.

2) Perkembangan kognitif Membantu anak untu mengenal benda-benda yang ada disekitarnya.

3) Kreatifitas Mengembangkan kreatifitas anak dalam bermain sendiri atau secara bersama.

4) Perkembangan sosial

Belajar berinteraksi dengan orang lain, mempelajari peran dalam kelompok.

5) Kesadaran diri (self awareness) Dengan bermain anak sadar akan kemampuannya sendiri, kelemahannya dan tingkah laku terhadap orang lain.
6) Perkembangan moral Dapat diperoleh dari orang tua, orang lain yang ada di sekitar anak.

7) Komunikasi

Bermain merupakan alat komunikasi utama pada anak yang masih belum dapat menyatakan perasaannya secara verbal.

4. Prinsip Pelaksanaan Terapi Bermain

Agar anak dapat lebih efektif dalam bermain di rumah sakit, perlu diperhatikan prinsip-prinsip sebagai berikut ${ }^{4}$ :

1) Permainan tidak banyak menggunakan energi, waktu bermain lebih singkat untuk menghindari kelelahan dan alat-alat permainannya lebih sederhana. Menurut Vanfeet, 2010 waktu yang diperlukan untuk terapi bermain pada anak yang dirawat di rumah sakit adalah $15-20$ menit. Waktu 15-20 menit dapat membuat kedekatan antara orangtua dan anak serta tidak menyebabkan anak kelelahan akibat bermain. Hal ini berbeda dengan Adriana, 2011, yang menyatakan bahwa waktu untuk terapi bermain 30-35 menit yang terdiri dari tahap persiapan 5 menit, tahap pembukaan 5 menit, tahap kegiatan 20 menit dan tahap penutup 5 menit. Lama pemberian terapi bermain bisa bervariasi, idealnya dilakukan $15-30$ menit dalam sehari selama 2-3 hari. Pelaksanaan terapi ini dapat memberikan mekanisme koping dan menurunkan kecemasan pada anak.

2) Mainan harus relatif aman dan terhindar dari infeksi silang. Permainan harus memperhatikan keamanan dan kenyamanan.

a) Sesuai dengan kelompok usia Tidak bertentangan dengan terapi.

Terapi bermain harus memperhatikan kondisi anak. Bila program terapi mengharuskan anak harus istirahat, maka aktivitasbermainhendaknya dilakukanditempattidur.

Permainan tidak boleh bertentangan dengan pengobatan yang sedang dijalankan anak. Apabila anak harus tirah baring, harus dipilih permainan yang dapat dilakukan di tempat tidur, dan anak tidak boleh diajak bermain dengan 
kelompoknya di tempat bermain khusus yang ada di ruang rawat.

b) Perlu keterlibatan orangtua dan keluarga.Banyak teori yang mengemukakan tentang terapi bermain, namun menurut Wong ${ }^{13}$, keterlibatan orangtua dalam terapi adalah sangat penting, hal ini disebabkan karena orangtua mempunyai kewajiban untuk tetap melangsungkan upaya stimulasi tumbuh kembang pada anak walaupun sedang dirawat si rumah sakit. Anak yang dirawat di rumah sakit seharusnya tidak dibiarkan sendiri. Keterlibatan orangtua dalam perawatan anak di rumah sakit diharapkan dapat mengurangi dampak hospitalisasi.

\section{Terapi Bermain Maggalenceng} (Congklak)

Maqgalaceng atau yang dikenal juga dengan sebutan aqgalacang adalah salah satu jenis permainan tradisional Melayu dari Sulawesi Selatan. Permainan tradisional ini mirip dengan permainan dakon yang populer di Jawa. Orang melayu di Sulawesi Selatan (Sulsel) memiliki beragam permainan tradisional yang unik dan khas, salah satunya adalah maqgalaceng (dalam bahasa Bugis) atau aqgalacang (dalam bahasa Makassar). (Aminah Maqgalaceng adalah permainan memindah-mindahkan butir-butir batu atau biji buah asem ke dalam lubanglubang (12 buah: 10 kecil dan 2 besar) pada tanah atau sebidang kayu Pabittei, Aminah. 2009. Permainan Rakyat Daerah Sulawesi Selatan. Sulawesi Selatan: Dinas Kebudayaan dan Pariwisata. ${ }^{14}$

Manfaat permainan tradisional maggalenceng, antara lain ${ }^{15}$ :

1) Dapat melatih otak kiri anak untuk berpikir.

2) Melatih strategi mengumpulkan angka terbanyak agar bisa.

3) Cengalahkan lawan, sepertinya sederhana, namun ketika dimainkan, otak kiri dan kanan aktif dengan perhitungan numerik.

4) Untuk perkembangan dan pembentukan otak kanan.

5) Melatih anak dalam bekerjasama.

6) Melatih emosi anak.

\section{PEMBAHASAN}

1. Kecemasan Akibat Hospitalisasi pada Anak Usia Sekolah

Hospitalisasi adalah suatu keadaan krisis pada anak, saat anak sakit dan dirawat di rumah sakit. Keadaan ini terjadi karena anak berusaha untuk beradaptasi dengan lingkungan asing dan baru, yaitu rumah sakit, sehingga kondisi tersebut menjadi faktor stressor bagi anak baik terhadap anak maupun orang tua dan keluarga ${ }^{5}$. Hal ini sejalan dengan penelitian yang dilakukan oleh $A$

Sartika $^{16}$ tentang hospitalisasi mempengaruhi tingkat kecemasan anak, didapatkan hasil bahwa ada pengaruh hospitalisasi terhadap tingkat kecemasan anak di Ruang Rawat Inap Puskesmas Tampa Padang Kabupaten Mamuju. Respon anak yang dirawat di Ruang Rawat Inap Puskesmas Tampa Padang dapat diobservasi seperti sering gelisah, rewel, dan selalu ingin ditemani saat menjalani proses perawatan, sering menangis dan mengatakan ingin pulang. A Sartika 22, juga menyatakan bahwa penyebab kecemasan yang dialami beragam, mulai dari rasa cemas terhadap petugas kesehatan seperti dokter, perawat, dan bidan, serta tindakan medis, cemas karena nyeri yang dialami, berada pada tempat dan lingkungan baru serta rasa cemas akibat perpisahan dengan saudaranya.

Pada kondisi cemas akibat perpisahan anak akan memberikan respon berupa perubahan perilaku. Respon perilaku anak akibat perpisahan di bagi menjadi tiga tahap, yaitu tahap protes ( phase of protest), tahap putus asa (phase of despair), dan tahap menolak (phase of denial). Pada tahap protes, reaksi anak dimanifestasikan dengan menangis kuat-kuat, menjerit,

memanggil orang tuanya atau menggunakan tingkah laku agresif agar orang lain tahu bahwa ia tidak ingin ditinggalkan orang tuanya serta menolak perhatian orang asing atau orang lain. Tahap putus asa menampilkan perilaku anak yang cenderung tampak tenang, tidak aktif, menarik diri, menangis berkurang, kurang minat untuk bermain, tidak nafsu makan, sedih, dan apatis. Tahap berikutnya dalah tahap menolak dimana anak samar-samar menerima perpisahan, membina hubungan dangkal dengan orang lain serta terlihat menyukai 
lingkungan. Anak mulai kelihatan gembira. Fase ini biasanya terjadi setelah anak berpisah lama dengan orang tua.

Pengaturan ansietas berhubungan dengan aktivitas dari neurotransmmiter Gamma Aminobutyric Acid (GABA) yang mengontrol aktivitas neuron di bagian otak yang berfungsi untuk pengeluaran ansietas. Mekanisme kerja terjadinya ansietas diawali dengan penghambatan neurotransmmitter di otakoleh GABA. Ketika bersilangan di sinaps dan mencapai atau mengikat ke reseptor GABA di membran postsinaps, maka saluran reseptor terbuka, diikuti oleh pertukaran ion-ion. Akibatnya terjadi penghambatan atau reduksi sel yang dirangsang dan kemudian sel beraktivitas dengan lamban. Mekanisme biologis ini menunjukkan bahwa ansietas terjadi karena adanya masalah terhadap

efisiensi proses neurotransmmitter. Neurotransmmitter sendiri adalah utusan kimia khusus yang membantu informasi bergerak dari sel saraf ke sel saraf. Jika neurotransmmitter keluar dari keseimbangan, pesan tidak bisa melalui otak dengan benar ${ }^{17}$. Tomb menyatakan bahwa hal ini dapat mengubah cara otak bereaksi dalam situasi tertentu yang mengakibatkan kecemasan.

Kecemasan pada anak sangat berpengaruh terhadap proses penyembuhan, yaitu dapat mengakibatkan menurunnya respon

imun. Berdasarkan konsep psikoneuroimunologi, yaitu proses hipotalamus hipofisis adrenal, dikatakan bahwa cemas psikologis akan berpengaruh pada hipotalamus, kemudian hipotalamus akan mempengaruhi hipofisis, sehingga hipofisis akan mengekspresikan ACTH (Adrenal Cortico Tropic Hormon) yang pada akhirnya dapat mempengaruhi kelenjar adrenal yang menghasilkan kortisol. Apabila cemas yang dialami pasien sangat berat, maka kelenjar adrenal akan menghasilkan kortisol dalam jumlah banyak, sehingga dapat menekan sistem imun. Adanya penekanan sistem imun inilah yang akan berakibat pada hambatan proses penyembuhan. Dalam penelitiannya, Pratiwi ${ }^{18}$ mengatakan bahwa hal tersebut dapat mengakibatkan waktu perawatan lebih lama, membutuhkan biaya perawatan yang lebih banyak, bahkan dengan penekanan sistem imun akan mempercepat terjadinya komplikasikomplikasi selama perawatan.

Saputra dan Farzin $4_{\text {juga }}$ menyatakan bahwa dampak jangka pendek dari kecemasan dan ketakutan yang tidak segera ditangani akan membuat anak melakukan penolakan terhadap tindakan perawatan dan pengobatan yang diberikan, sehingga berpengaruh terhadap lamanya hari rawat, memperberat kondisi anak dan bahkan dapat menyebabkan kematian pada anak, sedangkan dampak jangka panjang dari anak sakit dan dirawat yang tidak segera ditangani dapat mengakibatkan kesulitan dan kemampuan membaca yang buruk, memiliki gangguan bahasa dan perkembangan kognitif, menurunnya kemampuan intelektual dan sosial serta fungsi imun. Respon fisiologis yang dapat muncul meliputi perubahan pada sistem kardiovaskuler seperti palpitasi, denyut jantung meningkat, perubahan pola napas yang semakin cepat. Selain itu, kondisi hospitalisasi juga dapat mengakibatkan nafsu makan menurun, gugup, pusing, tremor, hingga insomnia, keluar keringat dingin dan wajah menjadi kemerahan.

Berdasarkan penelitian yang dilakukan oleh Jannah ${ }^{19}$ tentang tingkat stres pada anak usia sekolah dengan hospitalisasi di RSUD Labuang Baji Makassar dengan jumlah 19 reponden didapatkan hasil bahwa jenis tingkat stres yang banyak diderita oleh anak usia sekolah dengan hospitalisasi adalah tingkat stres sedang. Tingkat stres sedang memiliki persentase paling besar yaitu sebanyak 14 orang $(73,7 \%)$, tingkat stres yang dikategorikan stres berat sebanyak 5 orang $(26,3 \%)$, tingkat stres yang dikategorikan stres ringan tidak ada. Jadi, anak usia sekolah yang menjaani hospitalisasi rentan terhadap terjadinya stres. Hal ini sejalan dengan pernyataan Wong ${ }^{5}$ bahwa anak-anak cenderung mudah mendapat stressor dari penyakit dan hospitalisasi karena stress biasa muncul dari adanya perubahan dari situasi kesehatan dan kebiasaan sehari-hari serta disebabkan karena anak-anak cenderung memiliki mekanisme koping yang terbatas. 
Anak yang dipersiapkan dengan baik sebelum masuk rumah sakit akan mampu menerima keadaan rumah sakit. Masalah psikis yang penting pada pasien anak yang dirawat di rumah sakit yaitu rasa cemas dan takut terhadap lingkungan baru. Untuk itu perlu memberitahu kepada anak mengenai rumah sakit dengan cara orientasi ruangan dan peraturan rumah sakit. Orientasi ini meliputi pengenalan dengan ruangan, alat-alat, peraturan-peraturan, petugas, dan perawat yang ada, guna mencegah stress hospitalisasi ${ }^{20}$.

\section{Efektivitas Terapi Bermain Maggalenceng}

Dalam bermain diperlukan energi, namun bukan berarti anak tidak perlu bermain pada saat sedang sakit. Kebutuhan bermain pada anak sama halnya dengan kebutuhan bekerja pada orang dewasa. Pada saat kondisi anak sedang menurun atau anak terkena sakit, bahkan dirawat di rumah sakit, orang tua dan perawat harus jeli memilihkan permainan yang dapat dilakukan anak sesuai dengan prinsip bermain pada anak yang sedang dirawat di rumah sakit. Bermain ketika anak sedang di rawat di rumah sakit dapat mempercepat proses penyembuhan, tetapi jenis permainannya disesuaikan kondisi fisik, misalnya pilih permainan yang bisa dilakukan ditempat tidur.

Saputro dan Farzin menyatakan bahwa terapi bermain adalah salah satu aspek penting dari kehidupan anak dan efektif untuk mengatasi stress ketika dirawat di rumah sakit. Hospitalisasi menimbulkan krisis dalam kehidupan anak dan sering disertai stress berlebihan, maka anak-anak perlu bermain untuk mengeluarkan rasa takut dan cemas yang mereka alami sebagai alat koping dalam menghadapi stress. Hal ini sejalan dengan pernyataan

Sigmund Freud berdasarkanTeori Psycoanalytic mengatakan bahwa bermain berfungsi untuk mengekspresikan dorongan impulsif sebagai cara untuk mengurangi kecemasan yang berlebihan pada anak.

Terapi bermain merupakan terapi yang diberikan dan digunakan anak untuk menghadapi ketakutan, kecemasan dan mengenal lingkungan, belajar mengenai perawatan dan prosedur yang dilakukan serta staf rumah sakit yang $\mathrm{ada}^{4} \mathrm{Hal}$ ini didukung oleh penelitian yang dilakukan oleh Alini bahwa terdapat pengaruh pemberian

terapi bermain dengan tingkat kecemasan anak rata-rata kecemasan anak sebelum diberikan terapi bermain plastisin (playdought) adalah 14,07, sedangkan rata-rata kecemasan anak setelah diberikan terapi bermain plastisin (playdought) adalah 4,47. Dari data dapat ditarik kesimpulan bahwa terapi bermain efektif untuk menurunkan tingkat kecemasan pada anak yang menjalani hospitalisasi.

Penelitian yang juga menunjukkan bahwa terapi bermain efektif menurunkan kecemasan pada anak juga dilakukan oleh Kaluas tentang pemberian terapi bermain Puzzle dan bercerita pada anak didapatkan skor mean kecemasan sebelum dilakukan penerapan pada kelompok terapi bermain puzzle 34,71 dan kelompok terapi bercerita 37,71. Skor mean kecemasan sesudah dilakukan penerapan pada kelompok terapi bermain puzzle 28,71 dan kelompok terapi bercerita 31,12. Berdasarkan data, didapatkan bahwa pengaruh terapi bermain puzzle dan bermain terhadap respon kecemasan anak. Hal ini juga menunjukkan bahwa terapi bermain efektif untuk menurunkan kecemasan pada anak yang menjalani hospitalisasi.

Wong menyatakan bahwa anak usia sekolah memiliki karakteristik, yaitu

memperoleh kesenangan dari mengklasifikasi dan menata lingkungannya, mereka disibukkan dengan kegiatan mengoleksi banyak dan beragam benda seperti: gambar tempel, perangko, kerang, boneka, mobil, batubatu, dan segala sesuatu yang dapat

diklasifikasikan, bahkan mulai mngurutkan teman dan hubungan. Halini mendukung penelitian penulis yang meneliti tentang potensi terapi bermain maggalenceng dalam menurunkan kecemasan pada anak usia sekolah dimana salah satu alat yang digunakan dalam terapi bermain adalah biji-biji buah pohon asam atau kerikil. Selain itu, prinsip bermain dari maggalenceng adalah mengklasifikaikan biji-bijian tersebut.

Megawati ${ }^{21}$ menyatakan bahwa permainan maggalenceng dilakukan oleh 
dua orang. Dalam permainan mereka menggunakan papan yang dinamakan papan maggalenceng dan 98 (14x7) buah biji yang dinamakan biji

maggalenceng. Umumnya papan maggalenceng terbuat dari kayu dan plastik, sedangkan bijinya tebuat dari cangkang kerang, biji-bijian, batu-batuan, kelereng atau plastik.Pembelajaran

melalui permainan tradisional maggalenceng merupakan pembelajaran inovatif, kreatif, aktif dan menyenangkan yang mengangkat nilai budaya. Dalam menjalankan terapi bermain, perawat

perlu memiliki kreativitas dalam mengembangkan permainan maggalenceng.

Berdasarkan penelitian yang dilakukan oleh Akhida $^{22}$ ada pengaruh yang positif penggunaan metode permainan tradisional maggalenceng (congklak) terhadap perkembangan kognitif (berhitung) anak usia dini di TK Aisyiyah Beruk 1 Karanganyar Kelompok B Tahun Pelajaran 2013/2014. Teori

Cognitive-Developmental dari Jean Peaget, juga mengungkapkan bahwa bermain mampu mengaktifkan otak anak, mengintegrasikan fungsi belahan otak kanan dan kiri secara seimbang dan membentuk struktur syaraf, serta

mengembangkan pilar-pilar syaraf pemahaman yang berguna untuk masa datang. Berkaitan dengan itu pula otak yang aktif adalah kondisi yang sangat baik untuk menerima pelajaran ${ }^{23}$.

Permainan maggalenceng sangat baik untuk diterapkan menjadi terapi bermain pada anak hospitalisasi karena selain sebagai media terapi juga menjadi media edukasi, berdasarkan penyataan Plato bahwa anak akan lebih mudah memahami aritmatika ketika diajarkan melalui bermain. Pada waktu itu, Plato

mengajarkan pengurangan dan penambahan dengan membagikan buah apel pada masing-masing anak.

Eksperimen dan penelitian ini menunjukkan bahwa anak lebih mampu menerapkan aritmatika dengan bermain dibandingkan dengan tanpa bermain ${ }^{30}$.

Dalam penelitiannya, Rasyid menyatakan bahwa antara orang dewasa dan anak-anak, bermain memiliki perbedaan yang mendasar. Bermain bagi orang dewasa mempunyai fungsi

tersendiri sebagai bagian dari keseimbangan kehidupannya, anak-anak di lain pihak hanya mengenal bermain itu untuk memuaskan kemauan belaka. Pada anak yang menjalani hospitalisasi, dalam menjalankan terapi bermain sebaiknya mengacu pada tahapan tumbuh kembang anak, sedangkan

tujuan yang ditetapkan harus memperhatikan prinsip bermain bagi anak di rumah sakit, yaitu menekankan pada upaya ekspresi sekaligus relaksasi dan distraksi dari perasaan takut, cemas, sedih, tegang dan nyeri.

Salah satu prinsip bermain pada anak yang dirawat di rumah sakit adalah permainan tidak boleh bertentangan dengan pengobatan yang sedang dijalankan pada anak. Apabila anak harus tirah baring, harus dipilih permainan yang dapat dilakukan di tempat tidur, dan anak tidak boleh diajak bermain dengan kelompoknya di tempat bermain khusus yang ada di ruangan rawat. Berdasarkan pernyataan tersebut, maka terapi bermain maggalenceng merupakan solusi terapi bermain yang tepat karena pada prinsip bermainnya dapat dilakukan pada anak berada di tempat tidur dan juga bisa hanya dengan menggunakan satu tangan mengingat biasanya perawatan di rumah sakit akan membatasi kemampuan anak untuk melakukan banyak aktivitas. Permainan

maggalenceng juga yang tidak membutuhkan banyak energi, singkat, dan sederhana.

Ketika anak mulai bermain maggalenceng, anak akan belajar menghitung jumlah biji yang ada pada setiap lubang. Dengan terbiasa bermain anak akan mudah dalam hitungmenghitung, sehingga mereka belajar sambil bermain dalam suasana yang

menyenangkan. Hal ini dapat merangsang keluarnya hormon kebahagiaan, yaitu endorphin. Endorphin tidak saja digunakan untuk merilekskan bagian otot dan saraf, atau sebagai zat imun kita, melainkan juga mampu megurangi rasa sakit. Endorphin ini dihasilkan oleh kelenjar pituitary dan hipotalamus ketika kita bergembira, bercinta, maupun sedang orgasme dan riang. Endorphin mampu melepaskan sinyal rasa sakit yang berlebihan. Setelah cedera, dengan endorphin, kita dapat melakukan kontrol atas diri kita, sehingga memungkinkan kita untuk melakukan aktivitas sepanjang waktu. 
Kadar endorphin dalam tubuh manusia selalu berubah-ubah, yang tergantung pada aktifitas tubuh dan psikis ${ }^{24}$.

Selain ednorphin, ada zat lain yang membantu menumbuhkan perasaan bahagia dalam diri kita, yaitu serotonin. Serotonin adalah zat yang membantu menjaga suasana hati kita dibawah kontrol pikiran, menenagkan kecemasan, dan mengurangi depresi. Kekurangan kadar serotonin juga dapat menyebabkan kecemasan, apatis, rasa takut, perasaan tak berharga, insomnia (sulit tidur) dan kelelahan. Apabila semua hormon tersebut dihasilkan, maka kecemasan pada anak yang menjalani hospitalisasi akan menurun.

Bagi kehidupan orang Sulawesi Selatan, permainan maqgalaceng atau aqgalacang mengandung nilai-nilai, yaitu: Pertama, Permainan maqgalaceng atau aqgalacang memerlukan ketelitian dalam memutarkan biji-biji karena jika tidak, pemain tidak dapat memperkirakan jumlah biji dan dimana akan habis. Akibatnya ia akan sedkit mengumpulkan biji; Kedua, Olahraga, Dalam hal ini adalah otak karena dalam maqgalaceng atau aqgalncang, pemain harus teliti dan tajam ingatannya, misalnya dari manakah ia harus pertama kali mengambil biji agar tidak jatuh pada lubang yang kosong; Ketiga, Seni, nilai

ini tercermin dari wujud alat maqgalaceng atau aqgalncang itu sendiri yang tidak hanya sekedar dilubangi saja, terkadang alat maqgalaceng atau aqgalncang dihias dengan ukiran yang khas, seperti bentuk ular atau burung. Alat maqgalaceng atau aqgalncang bahkan sering dijadikan koleksi benda antik; Keempat, Melestarikan tradisi, maqgalaceng atau aqgalncang adalah ajaran leluhur Sulsel khususnya dan Indonesia umunya yang penting untuk dilestarikan. Meskipun saat ini tidak lagi difungsikan sebagai pelengkap adat

untuk orang meninggal, namun permainan maqgalaceng atau aqgalncang penting diberdayakan sebagai bukti kekayaan permainan tradisional Sulsel; Kelima, Belajar berhitung, nilai ini diperoleh dari pemain saat memutarkan biji-biji dimana pemain harus menghitung dengan cermat terlebih dahulu jumlah biji yang akan diputar, jangan sampai jatuh ke lubang yang kosong.
Menurut penulis, bermain maggalenceng sangat baik dan efektif apabila diterapkan pada anak hospitalisasi karena pada prinsip bermiannya tidak membuat anak yang sakit berpikir terlalu berat. Hanya memerlukan perhitungan sederhana dan kecermatan. Berpikir secara berlebihan tentunya akan membebani pikiran anak yang sedang sakit. Jika dibiarkan berlama-lama dapat mengakibatkan stress dan depresi.

\section{Prosedur Terapi Bermain Maggalenceng}
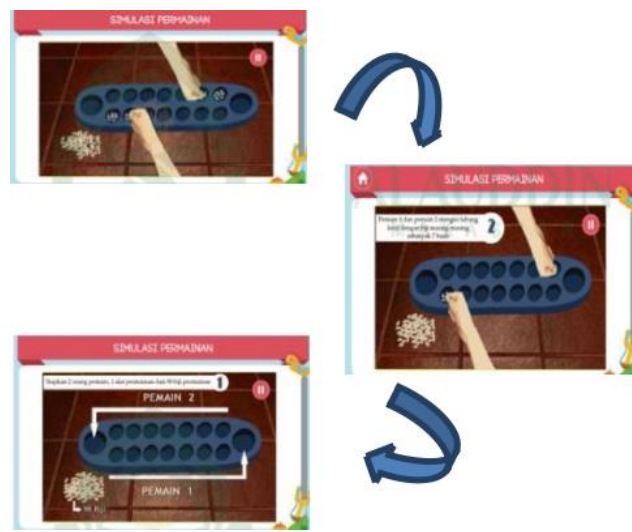

Gambar. Simulasi permianan maggalence ${ }^{11}$

Permainan maggalenceng dapat dilakukan oleh anak-anak dan orang dewasa laki-laki maupun perempuan. Untuk satu papan permainan hanya dapat dimainkan oleh dua orang.Namun, biasanya maggalenceng lebih diminati oleh perempuan, terutama anak-anak yang berusia 6-12 tahun ${ }^{25}$. Pernyataan tersebut mendukung penelitian penulis dimana penulis memfokuskan penelitian terapi bermain maggalenceng pada usia anak sekolah yaitu $6-12$ tahun.

Kegiatan bermain yang dijalankan mengacu pada tujuan yang telah

ditetapkan sebelumnya. Apabila permainan akan dilakukan dalam kelompok, uraikan dengan jelas aktivitas setiap anggota kelompok dalam permainan dan kegiatan orang tua setiap anak. Selama kegiatan bermain respon anak dan orang tua harus diobservasi dan menjadi catatan penting bagi perawat, bahkan apabila tampak adanya kelelahan pada anak permainan tidak boleh diteruskan. Proses dalam melakukan permainan merupakan hal yang terpenting, bukan semata-mata 
hasilnya. Adapun prosedur terapi tawarkan, sebagai berikut:

\begin{tabular}{|c|c|}
\hline Pengertian & $\begin{array}{l}\text { - Terapi bermain merupakan } \\
\text { terapi yang diberikan dan } \\
\text { digunakan anak untuk } \\
\text { menghadapi ketakutan, } \\
\text { kecemasan dan mengenal } \\
\text { lingkungan, belajar } \\
\text { mengenai perawatan dan } \\
\text { prosedur yang dilakukan } \\
\text { serta staf rumah sakit yang } \\
\text { ada }^{4} \text {. } \\
\text { - Maggalencengceng adalah } \\
\text { permainan memindah- } \\
\text { mindahkan butir-butir batu } \\
\text { atau biji buah asem ke } \\
\text { dalam lubang-lubang (12 } \\
\text { buah: } 10 \text { kecil dan } 2 \text { besar) } \\
\text { pada sebidang kayu atau } \\
\text { plastik. }\end{array}$ \\
\hline Tujuan & $\begin{array}{l}\text { - Meminimalisir tindakan } \\
\text { perawatan yang traumatis } \\
\text { - Mengurangi kecemasan } \\
\text { - Membantu mempercepat } \\
\text { penyembuhan } \\
\text { - Sebagai } \\
\text { komunikasi fasilitas } \\
\text { - Persiapan untuk } \\
\text { hospitalisasi atau surgery } \\
\text { - Sarana untuk } \\
\text { mengekspresikan } \\
\text { perasaan }\end{array}$ \\
\hline Kebijakan & $\begin{array}{l}\text { Dilakukan di rumah sakit } \\
\text { (ruang rawat inap) }\end{array}$ \\
\hline Petugas & Perawat \\
\hline Peralatan & 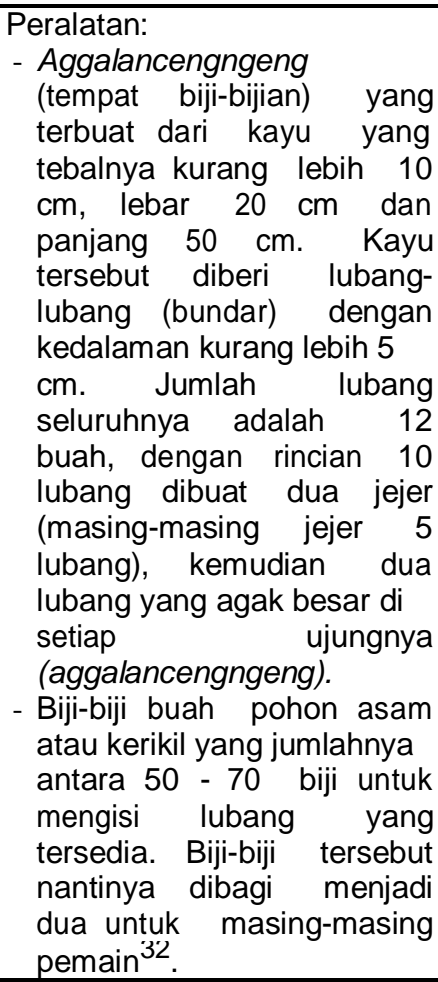 \\
\hline Prosedur & Tahap Prainteraksi \\
\hline
\end{tabular}

\begin{tabular}{|c|c|}
\hline Pelaksanaan & 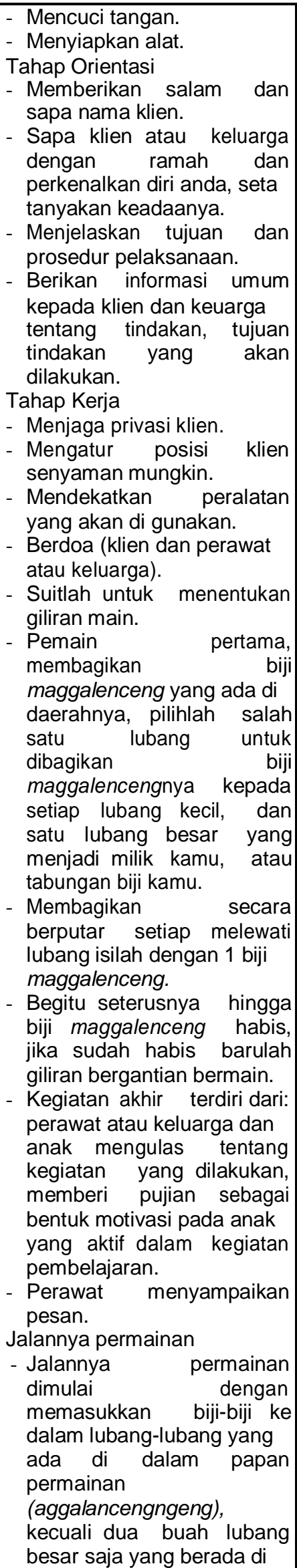 \\
\hline
\end{tabular}




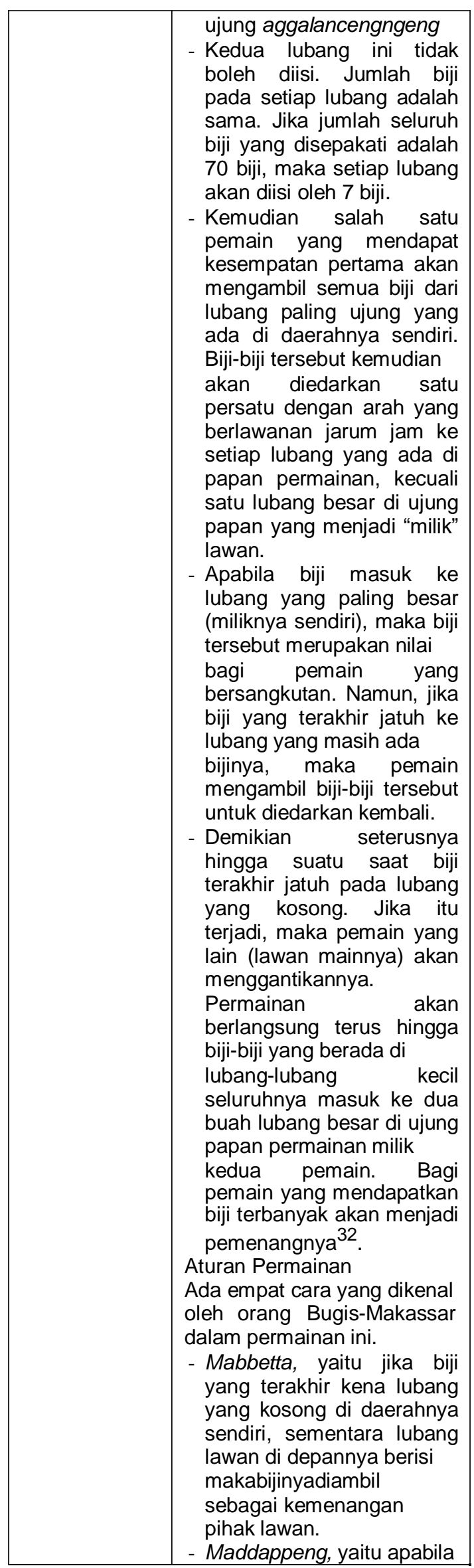

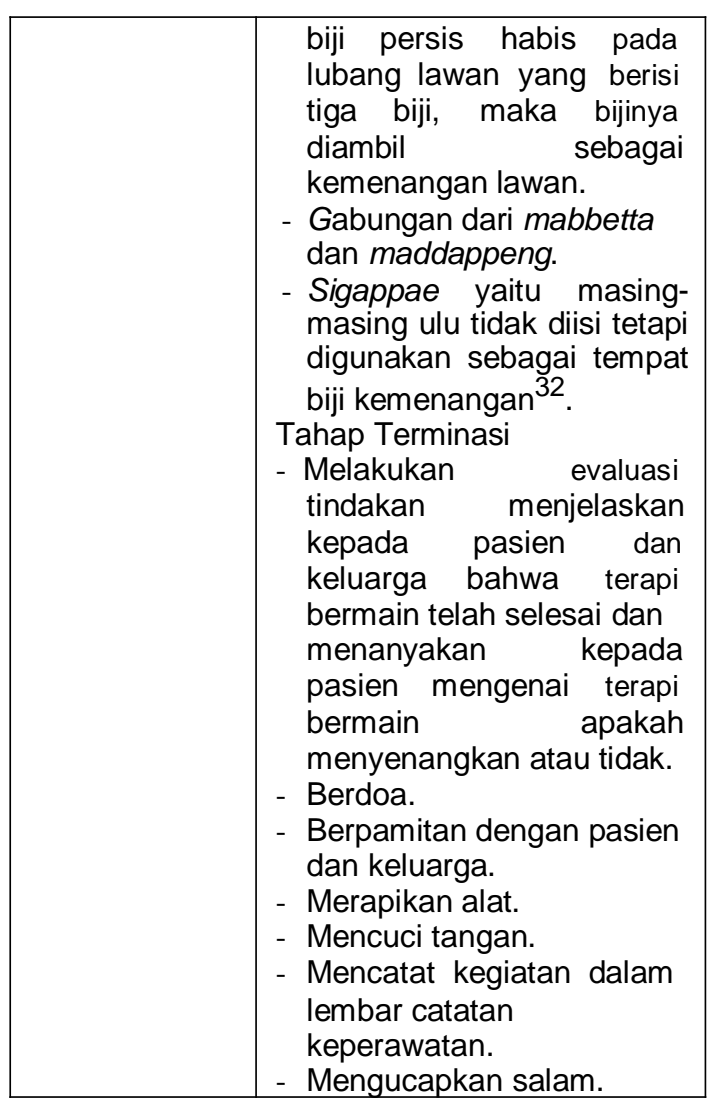

\section{KESIMPULAN}

Adapun kesimpulan dari penulisan ini adalah terapi bermain maggalenceng efektif digunakan sebagai metode untuk menurunkan kecemasan pada anak usia sekolah. Selain mampu mengaktifkan otak anak dan menurunkan kecemasan, maggalenceng juga memiliki nilai kearifan lokal dan mengandung nilai-nilai budaya tradisional Indonesia.

\section{SARAN} berikut:

Adapun saran dari penulisan ini sebagai

1. Untuk penelitian selanjutnya diharapkan peneliti dapat mengembangkan jenis-jenis terapi bermain yang memiliki nilai kearifan lokal dan efektif dalam menurunkan kecemasan serta dampak negatif pada anak yang menjalani hospitalisasi.

2. Untuk perkembangan dunia keperawatan di Indonesia, bermain maggalenceng dapat diaplikasi dalam perawatan anak, dengan menggunakan terapi bermain maggalenceng diharapkan angka kecemasan pada anak yang menjalani hospitalisasi di Indonesia dapat berkurang. 


\section{DAFTAR PUSTAKA}

${ }^{1}$ Apriliawati, A. 2011. Pengaruh biblioterapi terhadap tingkat kecemasan anak usia sekolah yang menjalani hospitalisasi di Rumah Sakit Islam Jakarta. Thesis. Depok: Universitas Indonesia.

${ }^{2}$ Survei Kesehatan Nasional (SUSENAS). (2010). Jumlah anak usia prasekolah di indonesia. 2015.

${ }^{3}$ Saputro, Heri dan Intan, Fazrin. 2017. Anak Sakit Wajib Bermain di Rumah Sakit: Penerapan Terapi Bermain Anak Sakit, Proses, Manfaat dan Pelaksanaannya. Ponorogo: Forum Ilmiah Kesehatan.

${ }^{4}$ Wong, D. L. 2004. Buku Ajar Keperawatan Pediatrik Vol. 2. Jakarta: EGC.

${ }^{5}$ Hawari H. Dadang, IQ, EQ, CQ dan SQ. 2013. "Criteria Sumber Daya Manusia (pemimpin) Berkualitas". Jakarta: Badai.

${ }^{6}$ Sutrimo A. 2012. Pengaruh Guided Imagery and Music (GIM) Terhadap Kecemasan Pasien Pre Operasi Sectiocaesarea di RSUD

Banyumas. S1. Keperawatan FK Universitas Jenderal Soedirman Purwokerto.

${ }^{8}$ Nursalam, dkk. 2005. Asuhan Keperawatan Bayi dan Anak untuk Perawat dan Bidan. Jakarta: Salemba Medika.

${ }^{9}$ Rasyid, Muhammad Rusydi. 2013. Bermain dan Berfantasi pada Anak: Suatu Pendekatan Psikologi Perkembangan dan Pendidikan Islam. Makassar: Alauddin University Press.

${ }^{9}$ Syisnawati dkk,. 2016. Menurunkan Kecemasan Anak Usia Sekolah Selama Hospitlisasi dengan Terapi Bermmain All Tangled Up. Journal Of Islamic Nursing. Vol 1 No 1, Juli 2016.

${ }^{10}$ Megawati. 2016. Rancang Bangun Aplikasi Pengenalan dan Simulasi Permainan Tradisional Nusantara Berbasis Android. Skripsi. Fakultas Sains dan Teknologi. UIN Alauddin Makassar.

${ }^{11}$ Hidayat, A. Aziz Alimul. 2008. Pengantar Ilmu Keperawatan Anak 1. Cetakan Keempat. Jakarta: Salemba Medika.

${ }^{12}$ Riyadi, Sujono dan Sukarmin. 2009. Asuhan Keperawatan pada Anak. Edisi Pertama.

${ }^{13}$ Wong, Yogyakarta: Graha Ilmu.

D.L...[et.al]. 2008. Buku Ajar Keperawatan Pediatrik Wong. Alih bahasa: Agus Sutarna, Neti. Juniarti, H.Y. Kuncoro. Editor edisi bahasa Indonesia: Egi Komara Yudha..... et al.]. Edisi 6. Jakarta : EGC.

${ }^{14}$ Pabittei, Aminah. 2009. Permainan Rakyat Daerah Sulawesi Selatan. Sulawesi Selatan: Dinas Kebudayaan dan Pariwisata.
${ }^{15}$ Heryanti, Vera. 2014. Meningkatkan Perkembangan Kognitif Anak Melalui Permainan Tradisional (Congklak). Skripsi. Universitas Bengkulu.

${ }^{16}$ A Sartika, Zulhaini dkk,. 2017. Hospitalisasi Mempengaruhi Tingkat Kecemasan Anak Todler. Jurnal Kesehatan Manarang: Vol 3, No 2.

${ }^{17}$ Tomb, David A. 2003. Buku Saku Psikiatri. Jakarta: EGC

${ }^{18}$ Pratiwi, Yusnita. 2012. Pengaruh Terapi Bermain Terhadap Respon Kecemasan Anak Usia Pra Sekolah Di Ruang Perawatan Anak Rsud Syekh Yusuf Kabupaten Gowa. Skripsi.Jurusan Keperawatan Fakultas Ilmu Kesehatan Universitas Islam Negeri Alauddin Makassar.

${ }^{19}$ Jannah, Nur Ifdatul. 2016. Gambaran Tingkat Stres pada Anak Usia Sekolah dengan Hospitalisasi di RSUD Labuang Baji. Skrpisi. Fakultas Kedokteran dan Ilmu Kesehatan. Universitas Islam Negeri Alauddin Makassar.

${ }^{20}$ Nursalam. (2008). Konsep dan penerapan metodologi penelitian ilmu keperawatan, pedoman skripsi, tesis dan instrumen peneliti. Jakarta : Salemba Medika.

${ }^{21}$ Megawati. 2016. Rancang Bangun Aplikasi Pengenalan dan Simulasi Permainan Tradisional Nusantara Berbasis Android. Skripsi. Fakultas Sains dan Teknologi. UIN Alauddin Makassar.

${ }^{22}$ Akhida, Tiar Asfiyatul. 2014. Permainan Tradisional Congklak Berpengaruh Terhadap Perkembangan Kognitif Anak Usia Dini di TK Aisyiyah Beruk 1 Karanganyar. Skripsi. Naskah Publikasi. Fakultas Keguruan dan Ilmu Pendidikan Universitas Muhammadiyah Surakarta.

${ }^{23}$ Rasyid, Muhammad Rusydi. 2013. Bermain dan Berfantasi pada Anak: Suatu Pendekatan Psikologi Perkembangan dan Pendidikan Islam. Makassar: Alauddin University Press.

${ }^{24}$ Muhammad, As'adi. 2011. Tertawalah biar sehat.Cetakan pertama. Jogjakarta : Diva Press.

${ }^{25}$ Departemen Pendidikan dan Kebudayaan. 1980. Permainan Rakyat Suku Bugis Makasar di Sulawesi Selatan. Ujung Pandang: Departemen Pendidikan dan Kebudayaan.http://ms.wikipedia.org/ 
